\title{
Seismic and Torsional Performance Improvement on Symmetric and Asymmetric Multi Storey Building with Post Tension Flat Slabs
}

\author{
Khadheeja Hussain ${ }^{1}$ \\ ${ }^{1}$ PG Student, \\ Department of Civil Engineering, \\ Ilahia college of Engineering and Technology, Mulavoor, \\ Ernakulum, Kerala, India
}

\author{
Rashida P. K ${ }^{2}$ \\ Department of Civil Engineering, \\ Ilahia college of Engineering and Technology, \\ Mulavoor, Ernakulum, Kerala, India
}

\begin{abstract}
Today Post-tensioning is a mature technology, providing efficient, economic and elegant structural solutions for a wide range of applications. Post-tensioned flat slab could be a better option compared to RCC flat slab, in respect of the cost of project and time of construction. The main aim of the project is to study the seismic performance of post-tensioned slab building with different geometric irregularity configuration and also analyze these post tensioned slab structures with shear wall. Posttensioned slab structures have weak resistance to lateral loads. So to provide stiffness to structures against lateral forces shear walls are used. In this paper, a study of $\mathbf{1 5}$ storey building in zone II is considered, and determine various parameters like base shear, storey drift, and displacement. Also, the building is analyzed with Post-tensioned flat slab by changing various location of shear wall. ETABS 2017 software is used for the analysis.
\end{abstract}

Key Words: Post-tensioned slat slab structure, RCC flat slab structure, shear wall, base shear, storey drift, storey displacement, ETABS

\section{INTRODUCTION}

Although concrete is a strong material for construction, it is not resistant to breakdown especially where longer concrete slabs are required like in a bridge or a length of a beam. For this, the concrete slab is tensioned with a process called pre-stressing and the slab of concrete which comes out after this process is known as post tension slab. This slab is much stronger as well as more durable than the normal concrete slabs. In today's world, where the modern engineering is finding new ways to build longer, more efficient and stronger structures, post tension slab becomes one of their chief requirements. Also due to the rapid increase in the shortage of land, construction of vertical structures is becoming a necessary part of our living. But this kind of construction brings challenges to counteract additional lateral load due to wind and earthquake. Flat slabs are one of the common floor systems for the construction of structures in earthquake sensitive areas. Flat slab structures have various advantages over conventional slab and beam structures. Flat slabs can be constructed by conventional reinforced concrete or by post-tensioning. Posttensioned flat slab could be a better option compared to RCC flat slab, in respect of the cost of project and time of construction. In multi-storey framed structures flat slabs have weak resistance to the lateral loads. To provide stability to structures from lateral loads, shear walls are used. It provides large stiffness and strength to structures and reduces damage to structures.

\section{Advantages of Post Tension Slab}

1. Reduced cost: Post tension slabs are excellent ways to construct stronger structures at an affordable price. There are many structures like parking garages as well as stadiums, since they are required to hold much more weight than average buildings; this slab becomes a viable option.

2. Flexibility in design: The designs made with this slab are sleek, require lesser space and give way to dynamic contours. All this makes them ideal for the expression of creativity in the building design.

3. Lesser usage of materials: Since the post tension slab is thin, the materials used with it are also lesser. Be it the thin beams, walls or supporting pillar of buildings, this compact concrete slab does not need bulky materials.

4. Durability: Being a very strong substitute of the normal concrete, it lasts longer.

\section{Disadvantages of the post tension slab}

1. Since there are a number of tendons and wires spread inside the post tension slab, it can result in corrosion. But largely, this tendency to corrode depends on the quality of the material used.

2. Complexity of work: The post tension slab can be made only by skillful professionals. The local workers may not have the necessary skills required to prepare this complex slab.

3. Poor workmanship can lead to accidents: The main problem with using post tension slab is that if care is not taken while making it, it can lead to future mishaps. Many a times, ignorant workers do not fill the gaps of the tendons and wiring completely. These gaps cause corrosion of the wires which may break untimely, leading to some untoward events.

The post tension slab is one of the building blocks of the modern architecture and builders cannot think of making skyscrapers, longer bridges and marvelous structures without using it. A skilled and experienced work is one of the key requirements while making these slabs, on the other hand, carelessness in the manufacture process may lead to disastrous results. 


\subsection{Objectives of the Work}

- Investigate the seismic performance of post tension slab building with different geometric irregularity configuration building

- To investigate the resistance performance study on improving the lateral stiffness by shear wall configuration

- To evaluate improvement on lateral displacement, story shear, drift

- To evaluate the torsional check limitation under irregularity condition

\subsubsection{Structure Detailing}

\section{A. Details of Building}

- Type of building: Symmetrical commercial building

- Plan dimension: $27.5 \mathrm{~m}$ x $27.5 \mathrm{~m}$

- Total height of building: $54 \mathrm{~m}$

- Height of each storey: $3.6 \mathrm{~m}$

- Total no. of storeys: 15

B. Material Properties of the Building

- Grade of concrete: M40

- Grade of steel: Fe500

C. Post-tension Strand Details

- Ultimate strength: $1860 \mathrm{~N} / \mathrm{mm} 2$

- Nominal area of strands: $98.7 \mathrm{~mm} 2$

- Strand diameter: $12.7 \mathrm{~mm}$

D. Sectional Properties of Building

- Beam dimensions for conventional structure: $300 \mathrm{~mm} x$ $350 \mathrm{~mm}$

- Thickness of slab for conventional structure: $150 \mathrm{~mm}$

- Thickness of slab for RCC and Post-tensioned flat slab structures: $200 \mathrm{~mm}$

- Thickness of shear wall: $250 \mathrm{~mm}$

- Dimension of drop panel: $2000 \mathrm{~mm}$ x 2000mm

- Column dimensions:

1. 1.1 to 5 storeys: $850 \mathrm{~mm} \times 850 \mathrm{~mm}$

2. 6 to 10 storeys: $750 \mathrm{~mm} \times 750 \mathrm{~mm}$

3. 11 to 15 storeys: $600 \mathrm{~mm} \times 600 \mathrm{~mm}$

E. Loads on the Building

- Seismic zone: Zone II

- Site type: II

- Importance factor: 1

- Wind speed: $39 \mathrm{~m} / \mathrm{s} 2$

- Terrain category: 4

- Live load on terrace: $1.5 \mathrm{kN} / \mathrm{m} 2$

- Live load on floors: $3 \mathrm{kN} / \mathrm{m} 2$

\subsubsection{Methodology}

The structure is modelled using ETABS. The different geometrical buildings such as symmetric like rectangle, $\mathrm{C}, \mathrm{T}$ and I shaped and unsymmetrical buildings like L shaped buildings are modelled in ETABS 2017. The results are tabulated and compared. Determines various parameters like base shear, storey drift, and displacement for different geometrical buildings and torsional performance of the posttensioned slab are computed, based on the comparisons the conclusions are drawn.
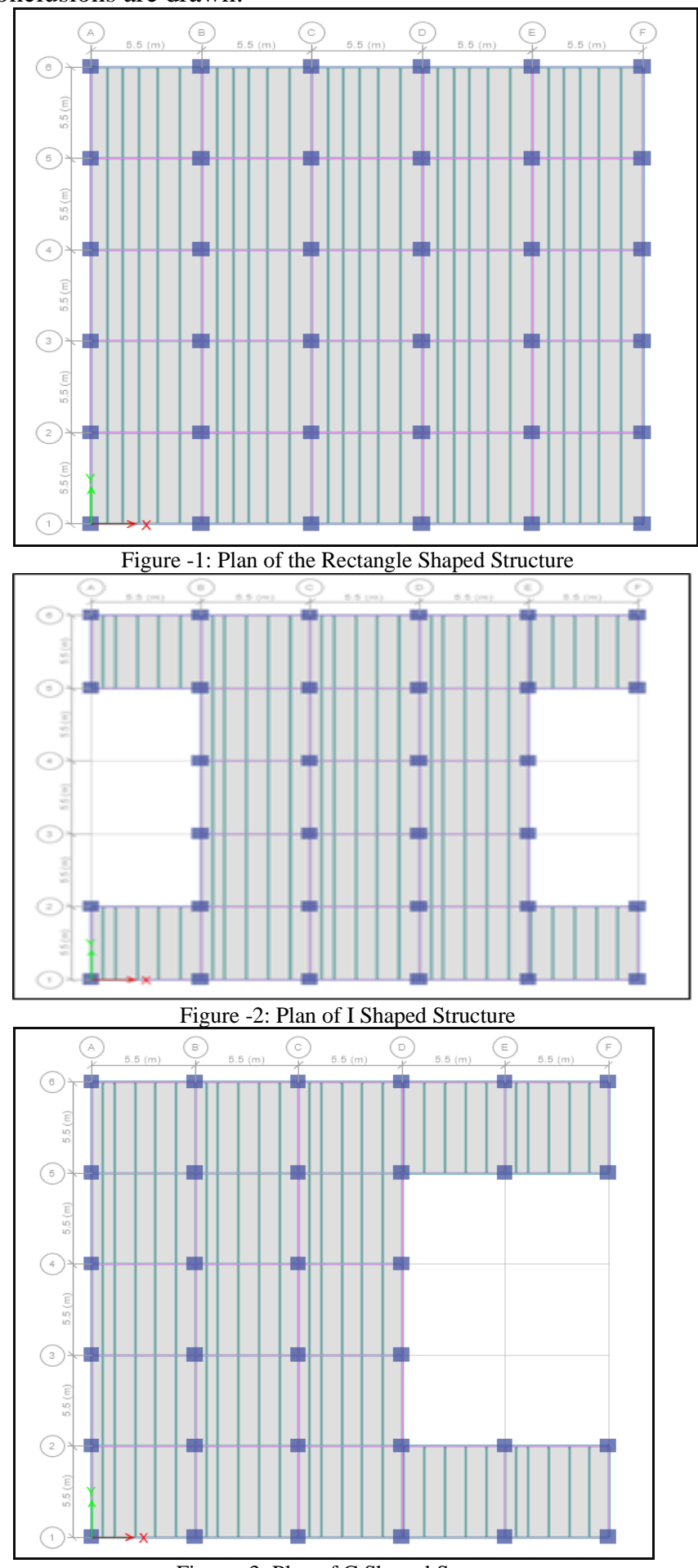

Figure -3: Plan of C Shaped Structure 


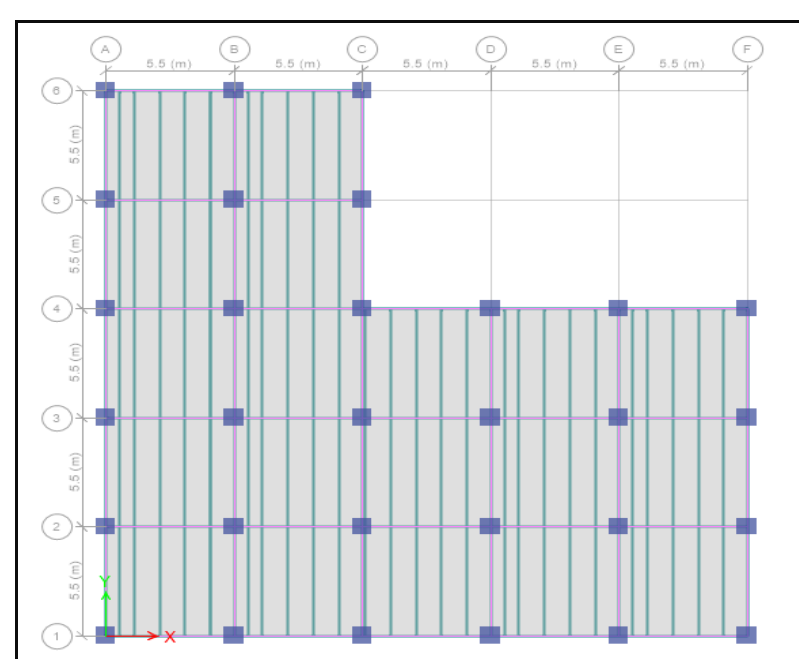

Figure -4: Plan of the L Shaped Structure

\section{RESULT AND DISCUSSSION}

Dynamic analysis for post tensioned slab building was done by using response spectrum analysis for earthquake zone II as per Indian standard code The results are obtained from the analysis of building models and compared for the parameters like base shear, storey displacement, storey drift etc.

\subsection{Comparison on Post Tensioned Slab Buildings Having Symmetric and Asymmetric Plan}

\subsubsection{Storey Displacement}

Storey displacement is the total displacement of a storey with respect to ground and is due to the lateral forces in $\mathrm{X}$ and $\mathrm{Y}$ directions. The data of displacement of sotrey in $\mathrm{X}$ and $\mathrm{Y}$ direction is collected for seismic loading from symmetric and asymmetric buildings.

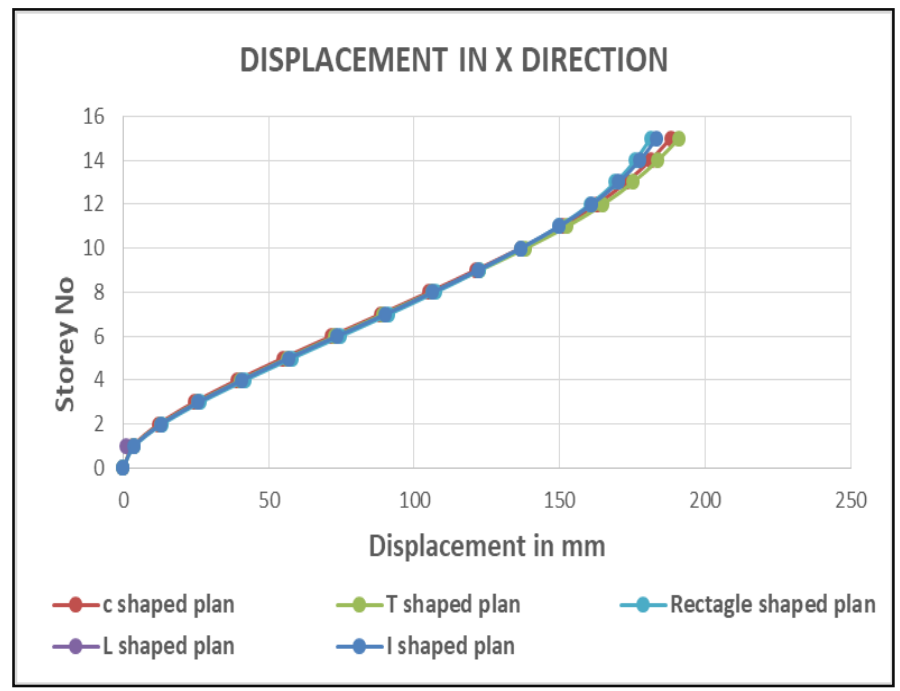

Chart -1: Graphical Representation of Storey Displacement in $\mathrm{X}$ Direction

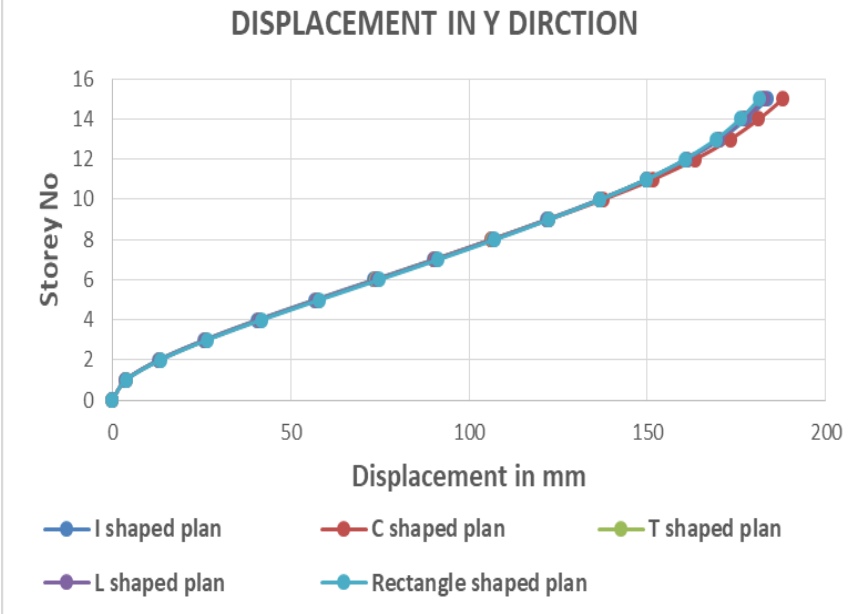

Chart- 2: Graphical Representation of Storey Displacement in Y Direction

Chart 1 and Chart 2 represents the variation of displacement of storey in $\mathrm{X}$ and $\mathrm{Y}$ - directions under seismic effect. It is found that the displacement of $\mathrm{L}$ shaped plan building shows slightly greater than others in X-direction. But C shaped plan building shows greater displacement in Y-direction. All buildings shows slightly difference in displacements.

\subsubsection{Storey Drift}

Storey drift is defined as difference between lateral displacements of one floor relative to the other floor. Total storey drift is the absolute displacement of any point relative to the base. As per IS.1893-2002 cl.7.11.1 the storey drift in any storey due to the minimum specified design lateral force with partial load factor 1.00 shall not be exceeding 0.004 times the storey height. Chart 3 and chart 4 represents the drift of each buildings in $\mathrm{X}$ and $\mathrm{Y}$ - directions under seismic effect.

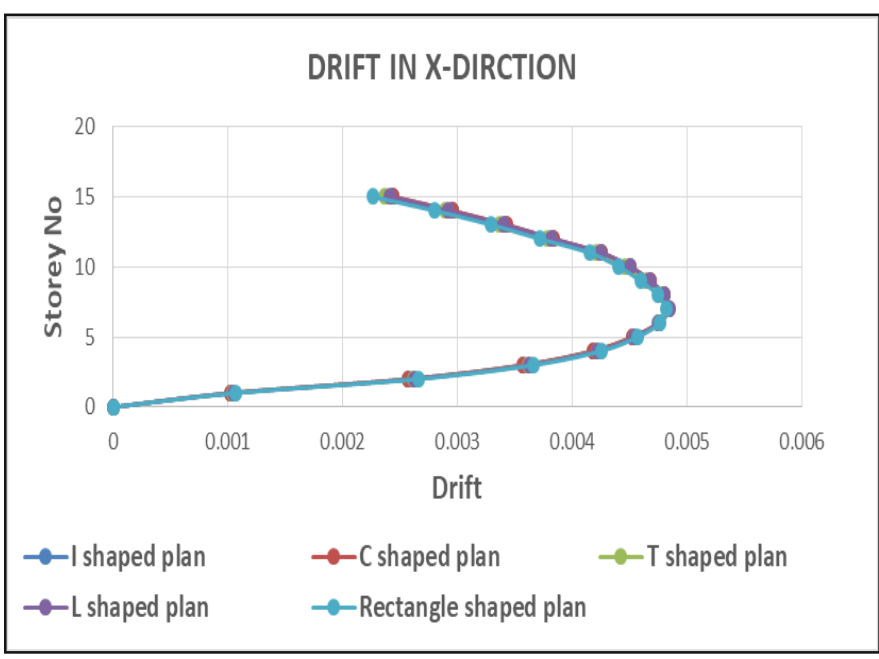

Chart -3: Graphical Representation of Storey Drift in X Direction 


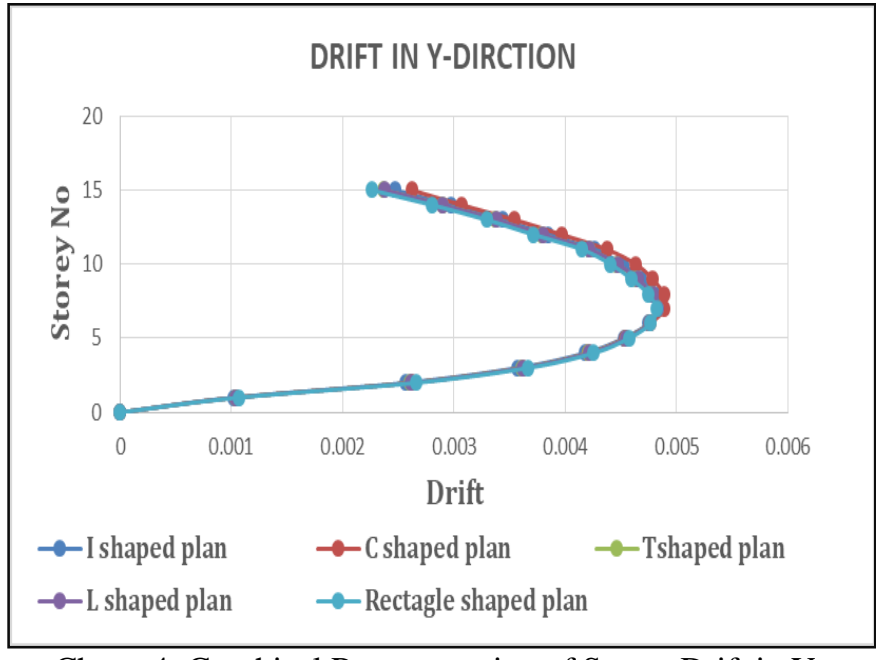

Chart -4: Graphical Representation of Storey Drift in Y Direction

As per IS code all buildings are not in the limit. All buildings fails under seismic loads. Comparing each buildings $\mathrm{L}$ shaped building shows more drift in X-direction. The storey drift of L shaped building is $21.1 \%$ higher than the limit. But in Y-direction $\mathrm{C}$ shaped building shows more storey drift, which is $22.25 \%$ higher than the limit.

\subsubsection{Storey Shear}

Seismic forces are lateral loads which intern will create total reactive forces at column base in direction opposite to that of lateral load i.e. (sum of lateral loads = base shear) this overall reactive force is base shear. But the load is not applied on base alone, as the lateral load is applied along the height of building and building in turn has different stiffness and masses along its height in different storey, so the reactive force in each storey due to lateral load varies and this reactive force is storey shear. Roughly storey shear can also be seen as distribution of base shear along its storey based on its stiffness and mass.

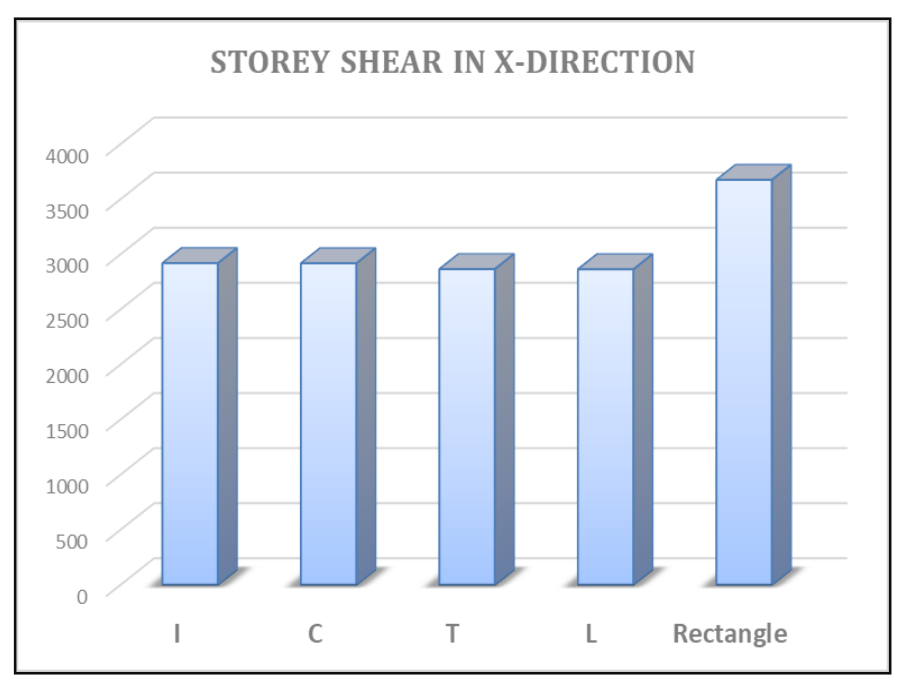

Chart -5: Graphical Representation of Storey shear in X Direction

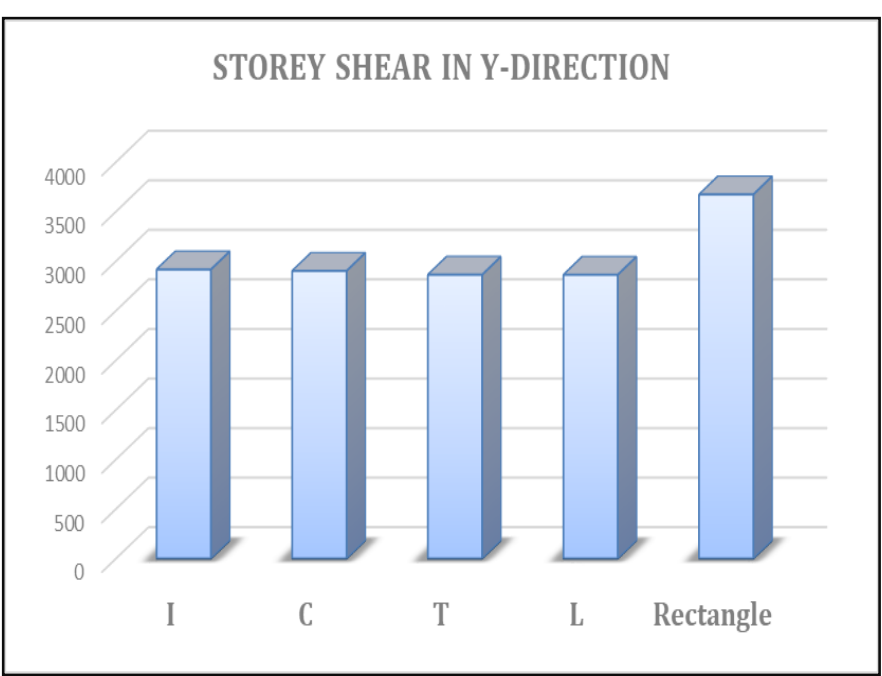

Chart -6: Graphical Representation of Storey shear in Y Direction

The storey shear is maximum at ground level and keeps on decreasing towards the top storey of the structure. The base shear of rectangle shaped structure is more than other structures both in $\mathrm{X}$ and $\mathrm{Y}$ directions. $\mathrm{L}$ shaped structure has lower base shear, which is $22 \%$ lower than compared with rectangle shaped buildings both in $\mathrm{X}$ and $\mathrm{Y}$ directions.

\subsection{Comparison on Behaviour of Post-tensioned Slab structures with Shear wall at various locations}

\subsubsection{Storey Displacement}

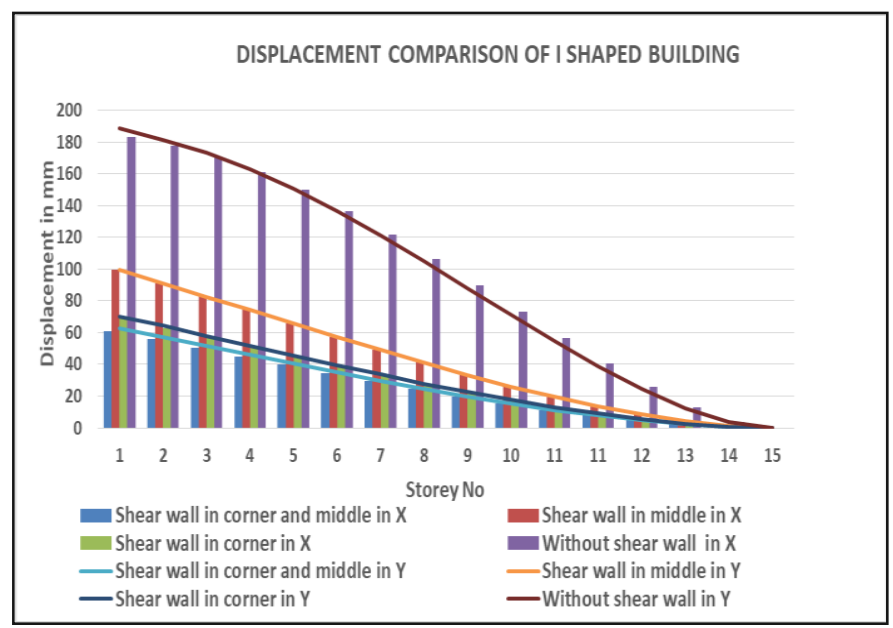

Chart -7: Graphical Representation of Storey Displacement of I building 


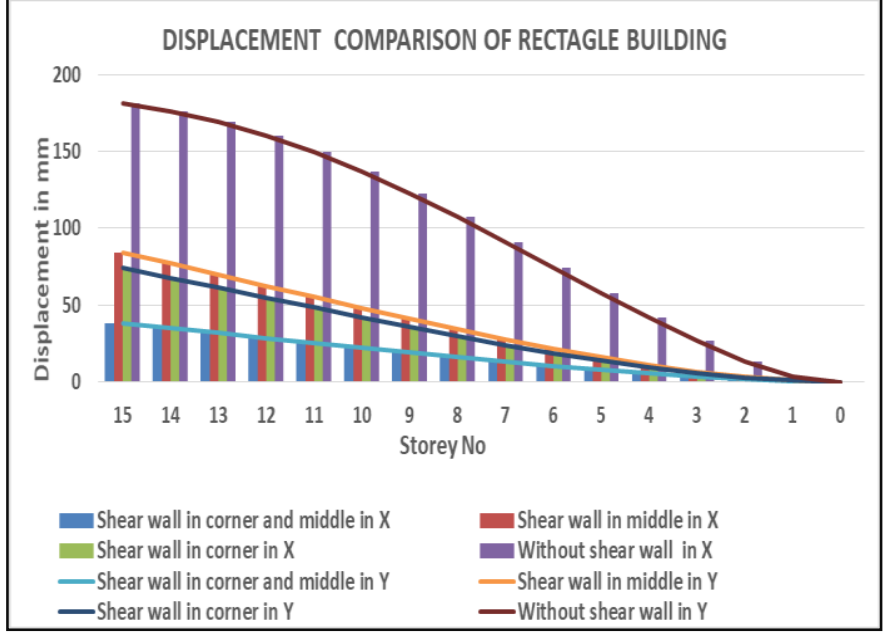

Chart -8: Graphical Representation of Storey Displacement of Rectangle Building

It is found that in both $\mathrm{X}$ and $\mathrm{Y}$ directions building without shear wall shows greater displacement. After providing shear wall displacement of buildings reduced, and which is in the permissible limits. In case of I building, storey displacement in both $\mathrm{X}$ and $\mathrm{Y}$ direction is low in shear walls provided in both corner and middle.

In case of rectangle buildings it is found that buildings having shear wall in both $\mathrm{X}$ and $\mathrm{Y}$-directions shows lower displacement than buildings without shear wall and its rate of decrease is same in both direction, which is $79.03 \%$. Since both rectangle and I shaped building shows symmetry in $\mathrm{X}$ and $\mathrm{Y}$ direction it shows relatively same performance in displacement.

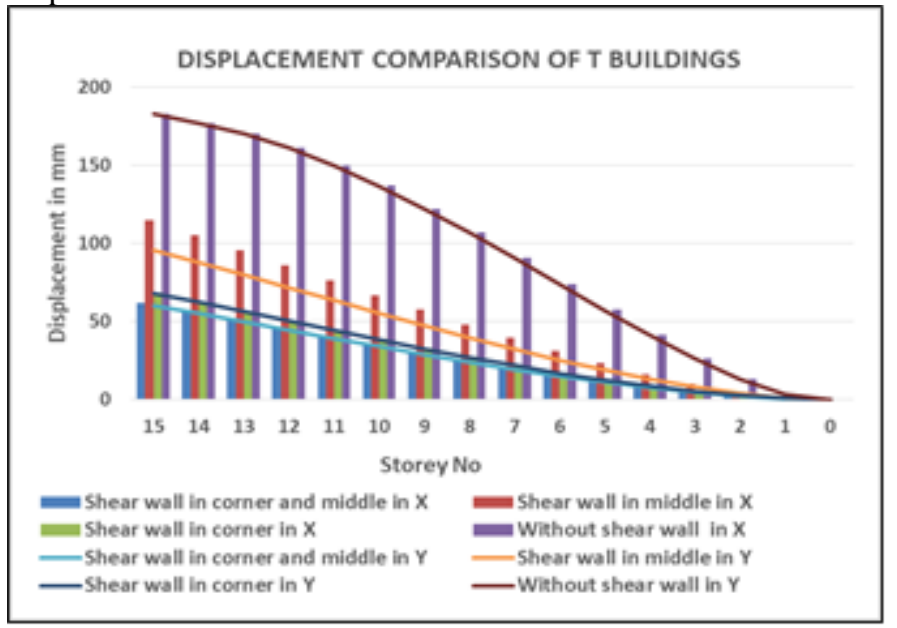

Chart -9: Graphical Representation of Story Displacement of T Shaped Building

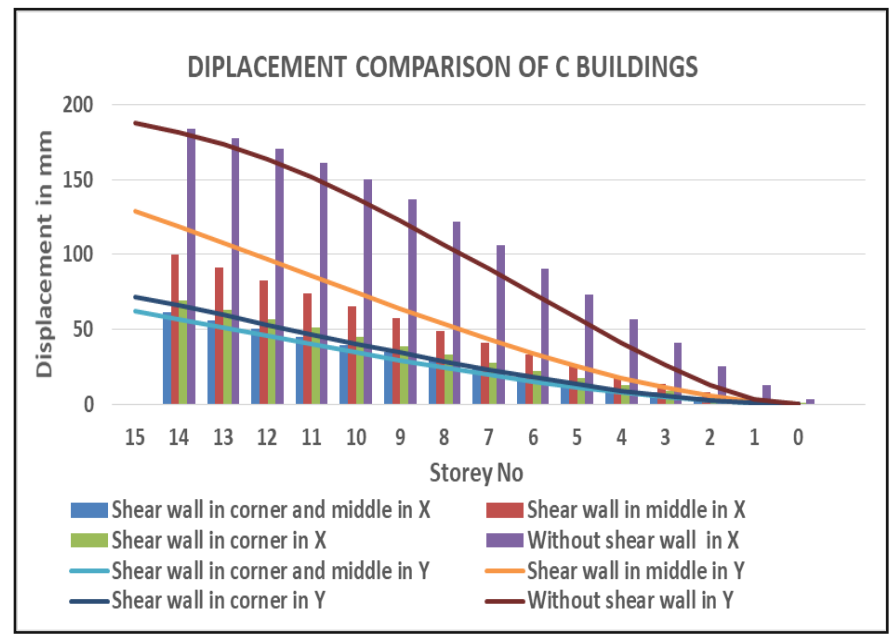

Chart -10: Graphical Representation of Story Displacement of C Shaped Building

Both $\mathrm{C}$ and $\mathrm{T}$ shaped buildings shows its symmetry in either $\mathrm{X}$ or $\mathrm{Y}$ axes. In both buildings the storey displacement is lowered in case of shear wall are provided both in corner and middle. In $\mathrm{T}$ shaped buildings the storey displacement comparatively low in $\mathrm{X}$ and $\mathrm{Y}$ when shear wall provided in both corner and middle. Also buildings with shear walls in middle shows poor performance both in $\mathrm{X}$ and $\mathrm{Y}$ directions. In $\mathrm{C}$ shaped buildings the performance is same as that of $\mathrm{T}$ Buildings.

Chart 11 represents the displacement variation of 1 buildings. It is found that the displacement is lowered in both shear wall provided in corner and in both corner and middle. But in case of shear walls provided in middle shows poor performance. The $\mathrm{L}$ shaped buildings asymmetric in both $\mathrm{X}$ and $\mathrm{Y}$ axes.

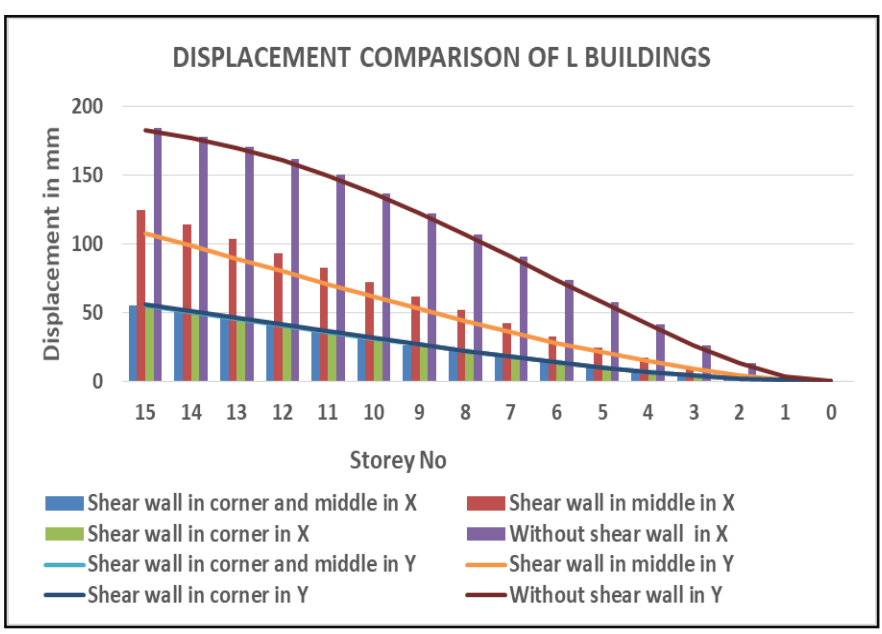

Chart 15: Graphical Representation of Story Displacement of L Shaped Building 


\subsubsection{Storey Drift}

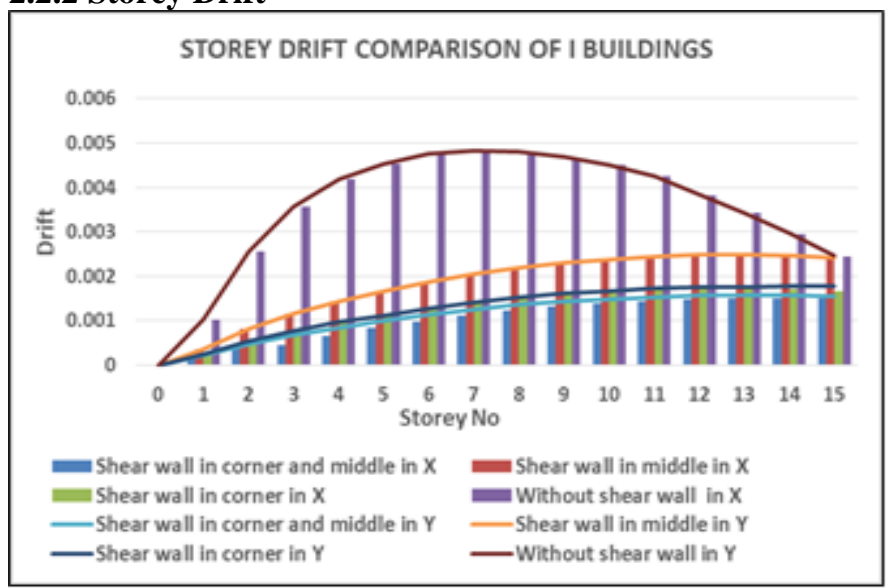

Chart -12: Graphical Representation of Story Drift of I Shaped Building

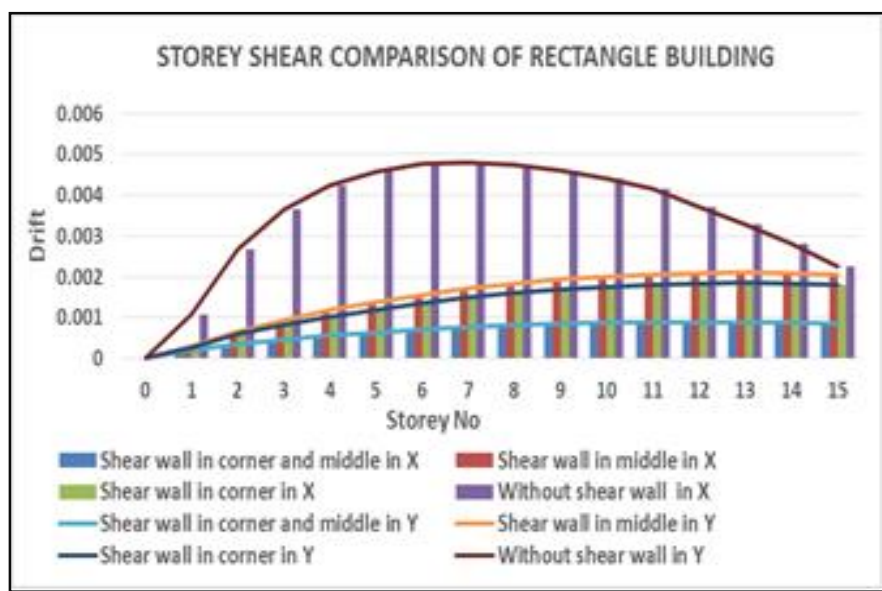

Chart -13: Graphical Representation of Story Drift of Rectangle Shaped Building

In both rectangle and I shaped buildings the story drift value is reduced to its permissible limit after providing shear walls. In both buildings the storey drift is lower in case of shear walls provided in both middle and corner. In rectangle shaped building the storey drift value is reduced into $77.65 \%$ from its permissible value as per Indian code. In case of I building drift value is reduced to $62.225 \%$ from its permissible value.

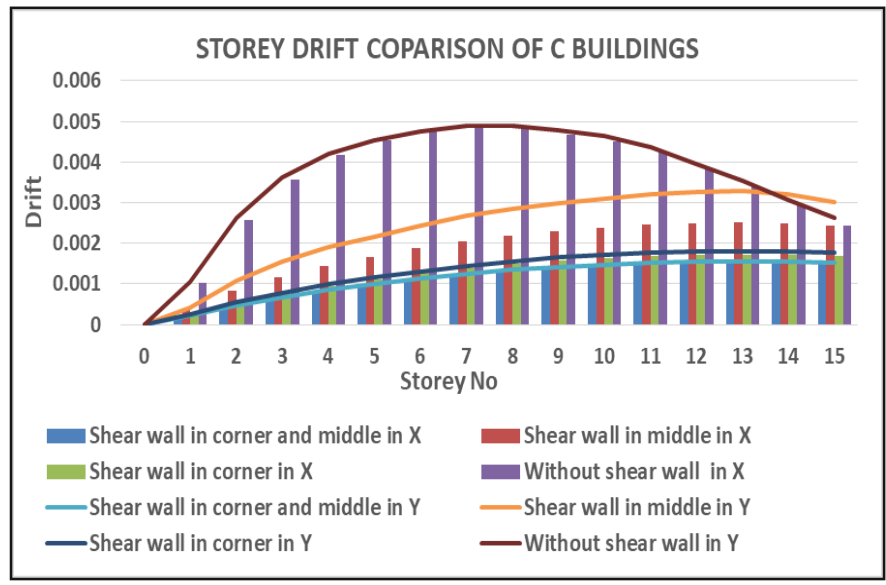

Chart -14: Graphical Representation of Story Drift of C Shaped Building

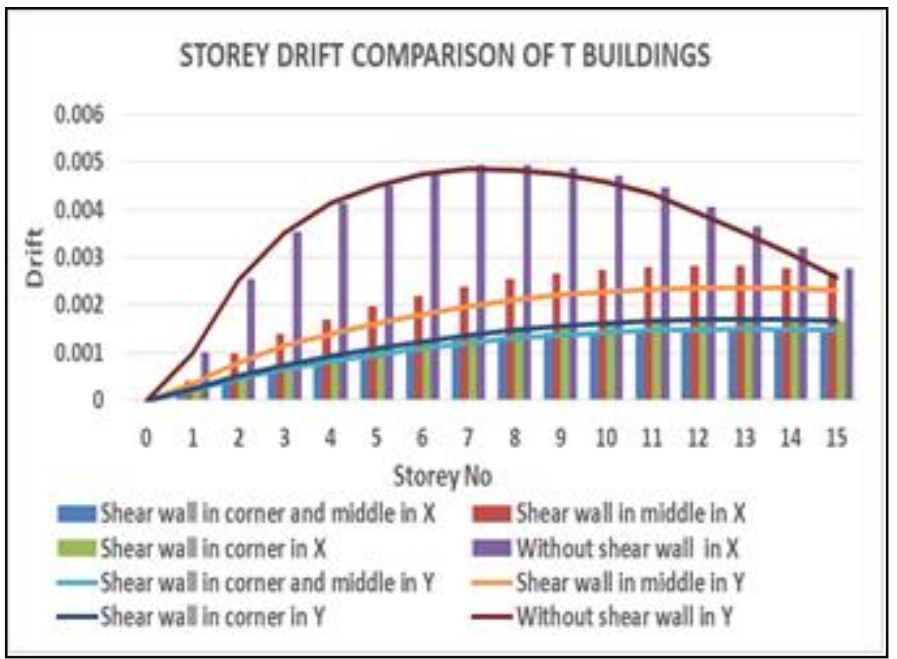

Chart -15: Graphical Representation of Story Drift of T Shaped Building

In case of $\mathrm{C}$ buildings the story drift is reduced when shear walls provided in both corner and middle. It's also same in $\mathrm{T}$ building. In $\mathrm{C}$ buildings it's reduced to $61.975 \%$ and in $\mathrm{T}$ buildings $62 \%$ is reduced.

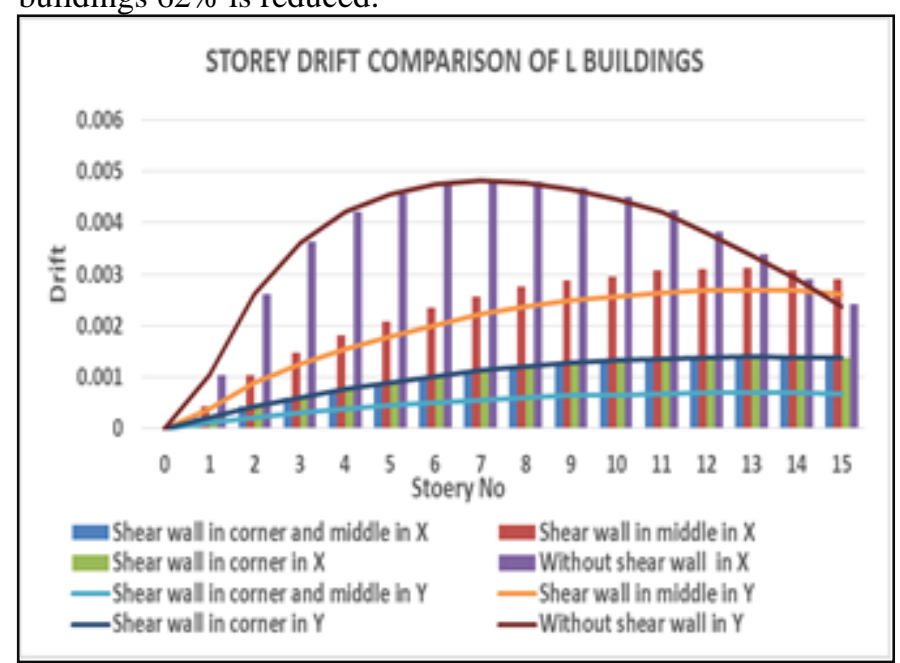

Chart -16: Graphical Representation of Story Drift of L Shaped Building

Storey drift of L shaped Buildings having shear walls in corner and middle reduced its value to $65.95 \%$ in $\mathrm{X}$ direction and $82.8 \%$ in $\mathrm{Y}$ direction from its permissible limit.

\subsubsection{Time Period}

Time required for the undamped system to complete one cycle of free vibration is the natural time period of vibration of system in unit of second.

Time period depends on mass of building and it indicates flexibility of building. The number of mode increases, the value of time period decreases. In case of symmetric building the time period along $\mathrm{X}$ and $\mathrm{Y}$ direction is same. But in asymmetric buildings it shows variation. From below chart it 
is observed that time period of $\mathrm{C}$ shaped building is more than other planned building. From below charts it is observed that symmetric building has lower time period than asymmetric buildings.

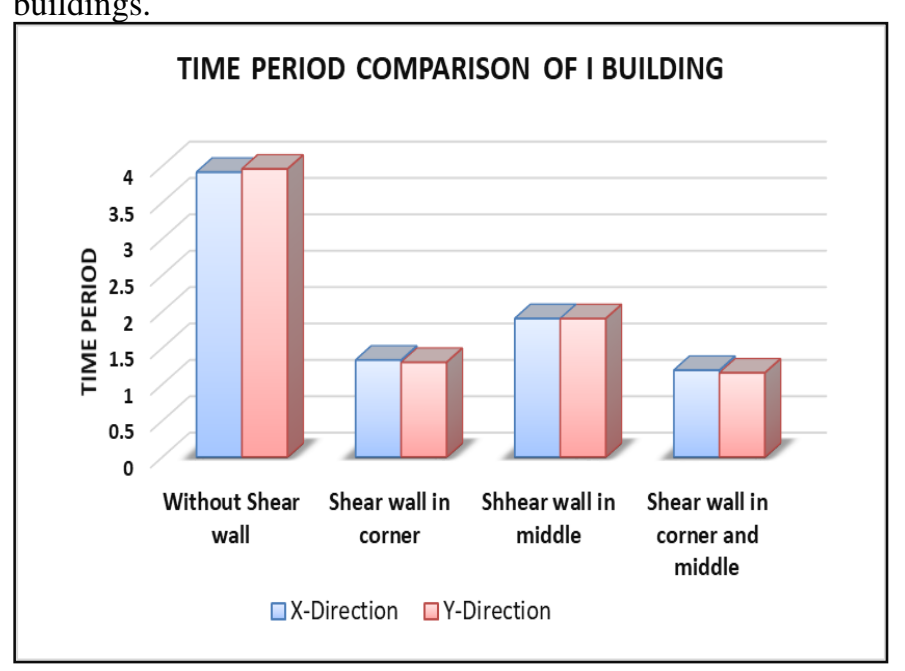

Chart -17: Graphical Representation of Time Period of I Shaped Building

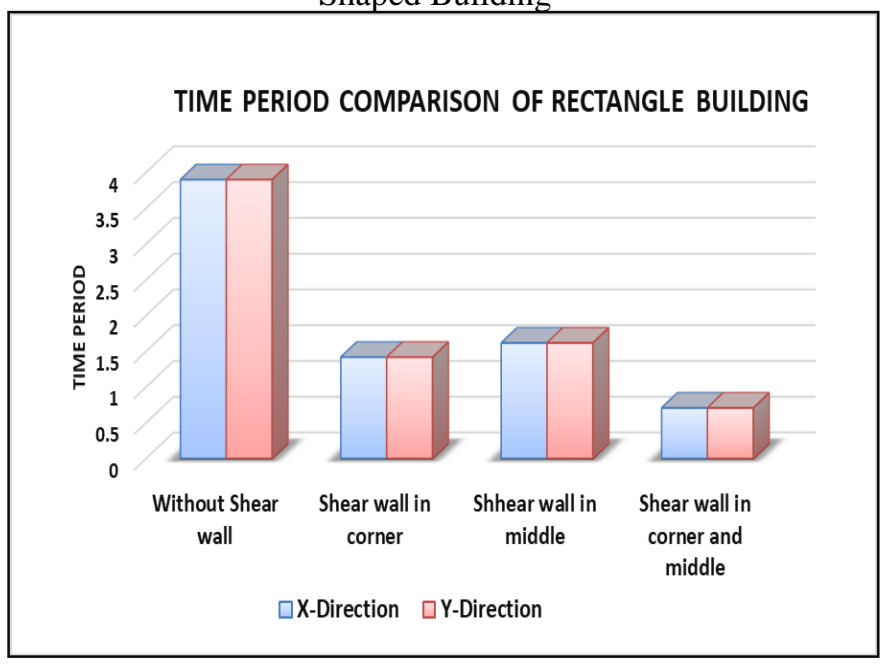

Chart -18: Graphical Representation of Time Period of Rectangle Shaped Building

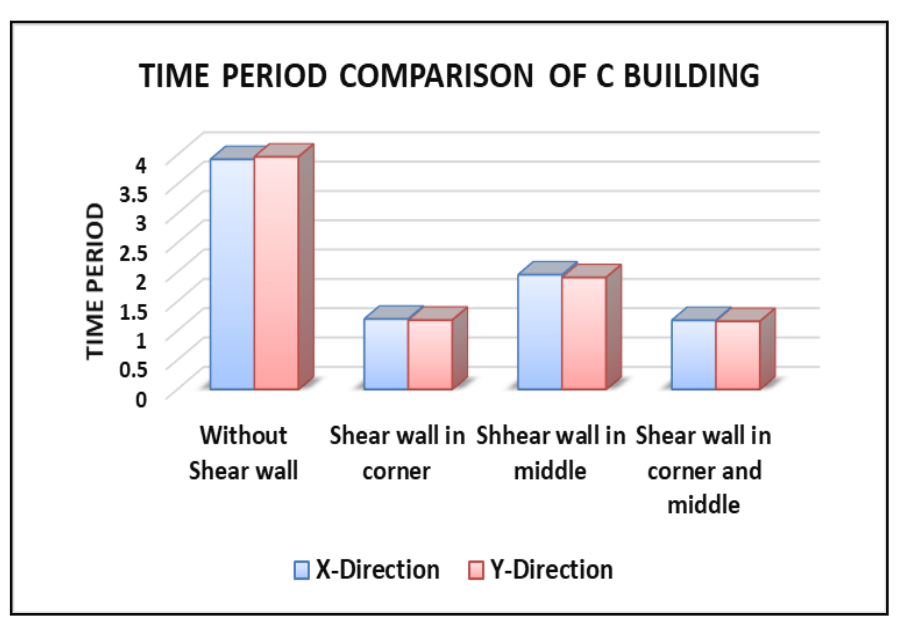

Chart -19: Graphical Representation of Time Period of C Shaped Building

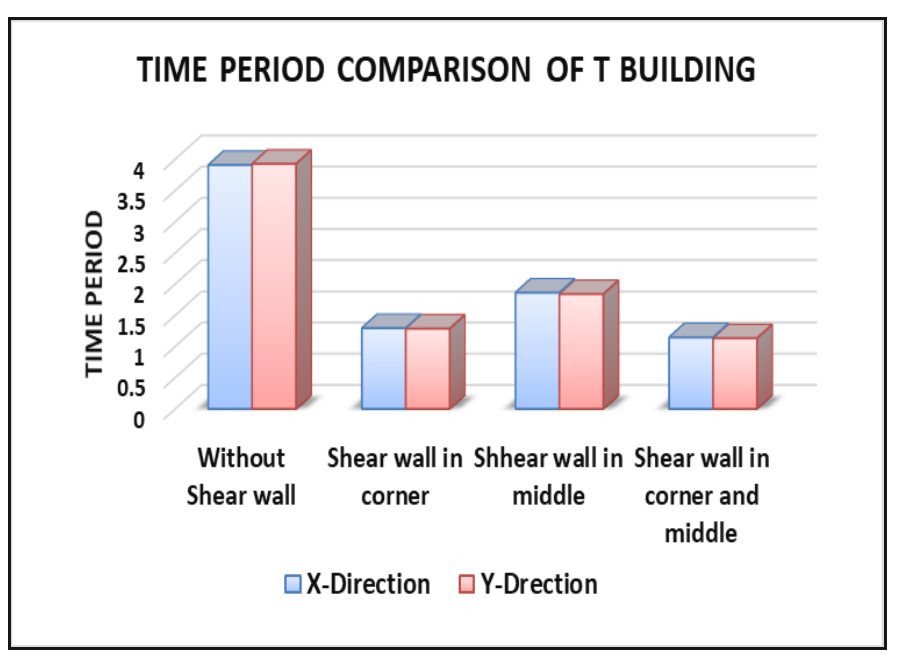

Chart -20: Graphical Representation of Time Period of T Shaped Building

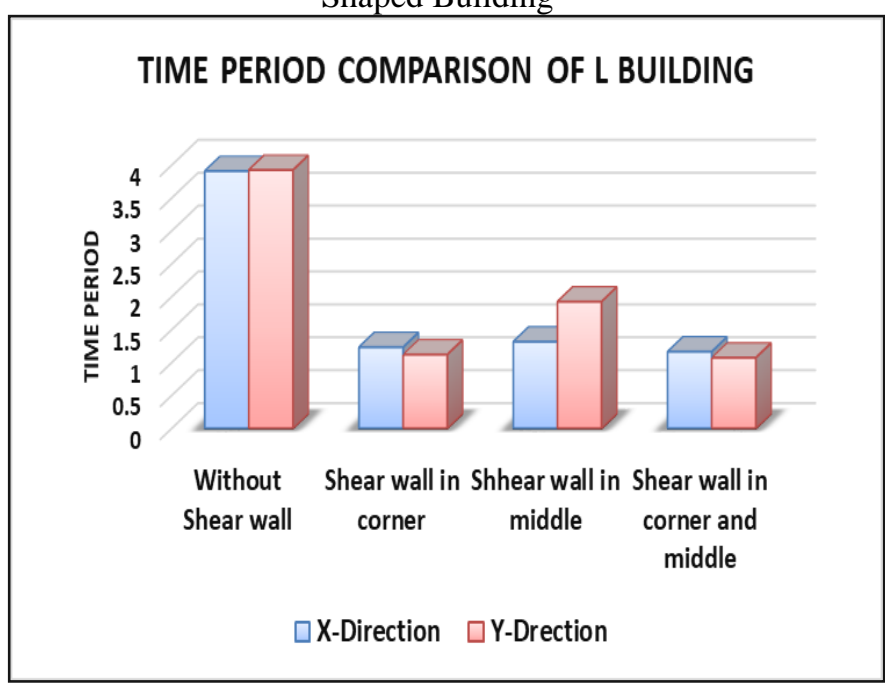

Chart -21: Graphical Representation of Time Period of C Shaped Building

\subsubsection{Torsional Irregularity}

Torsion is created when the Centre of mass (CM) and the Centre of rigidity or resistance (CR) in the building do not coincide. The distance between these two points is referred to as torsion eccentricity. Torsional effects can develop only in buildings with rigid diaphragms. Torsion in buildings during earthquake is caused due to various reasons and the most common is unsymmetrical distribution of mass and stiffness along the height of building. A special care and attention must be taken, so that, torsional effects do not avert the ductile behaviour of the structure. 
Table -1: Torsional Irregularity of Buildings

\begin{tabular}{|c|c|c|c|c|c|}
\hline \multirow{2}{*}{\multicolumn{2}{|c|}{\begin{tabular}{|l|} 
\\
SHAPE OF \\
BUILDING \\
S \\
\end{tabular}}} & \multicolumn{4}{|c|}{ SHEAR WALL CONDITION } \\
\hline & & $\begin{array}{l}\text { Without } \\
\text { Shear Wall }\end{array}$ & In Corner & In Middle & $\begin{array}{l}\text { Both Middle } \\
\text { And Corner }\end{array}$ \\
\hline \multirow[b]{2}{*}{ I } & $X$ & 1 & 1 & 1 & 1 \\
\hline & $\mathrm{Y}$ & 1 & 1 & 1 & 1 \\
\hline \multirow{2}{*}{$\begin{array}{l}\mathrm{Re} \\
\mathrm{cta} \\
\mathrm{ngl} \\
\mathrm{e}\end{array}$} & $X$ & 1 & 1 & 1 & 1 \\
\hline & $\mathrm{Y}$ & 1 & 1 & 1 & 1 \\
\hline \multirow{2}{*}{ C } & $X$ & 1 & 1 & 1 & 1 \\
\hline & $\mathrm{Y}$ & 1.02 & 1.05 & 1.25 & 1.002 \\
\hline \multirow{2}{*}{$\mathrm{T}$} & $X$ & 1 & 1.02 & 1.19 & 1.04 \\
\hline & Y & 1 & 1 & 1.05 & 1 \\
\hline \multirow{2}{*}{$\mathrm{L}$} & $X$ & 1.006 & 1.04 & 1.23 & 1.04 \\
\hline & $\mathrm{Y}$ & 1.008 & 1.04 & 1.1 & 1.05 \\
\hline
\end{tabular}

As per code the value should not greater than 1.2. Here in some conditions such as in case of $\mathrm{C}$ shaped building along $\mathrm{Y}$ and 1 shaped buildings along $\mathrm{X}$ shows torsional irregularity greater than 1.2

\section{CONCLUSIONS}

This is the summary of project work for post-tensioned slab buildings with different geometric plan irregularities in seismic zone II with type II medium soil. From the above charts following conclusions have been drawn:

1. Storey displacement is high at top storey and least at the base of the structures. L shaped plan building shows slightly greater storey displacement in X-direction. But $\mathrm{C}$ shaped plan building shows greater displacement in $\mathrm{Y}$-direction. When shear wall provided, the displacement of each building reduced. And in each case building having shear walls in both corner and middle shows better performance.

2. Storey drift follows a parabolic path along storey height with maximum value lying somewhere near the storey 7 . But after providing it changes to near the storey 14 . The post tensioned slab buildings shows poor performance during earthquake. Therefore, Storey drift of each buildings higher than permissible value 0.004 . After providing shear walls the drift value of each buildings comparatively reduced. In each buildings shear walls at corner and middle shows good performance in both storey displacement and storey drift.

3. The base shear is maximum at ground level and keeps on decreasing towards the top storey of the structure. The story shear is maximum in rectangular shaped building and minimum in L shaped buildings. After providing shear walls stoery shear increased. Story shear increasing with increase in number of shear wall. Story shear of L shaped building $22 \%$ lower than rectangular shaped buildings.

4. The time period is maximum at mode 1,2 and 3. After mode 3 time period reduces drastically. In case of symmetric building the time period along $\mathrm{X}$ and $\mathrm{Y}$ direction is same. But in asymmetric buildings it shows variation. Time period of $\mathrm{C}$ shaped building is more than other shaped building. Symmetric building has lower time period than asymmetric buildings. After providing shear wall its time period decreased. Buildings with shear walls at corner and middle shows lower time period. In $\mathrm{X}$ direction, the percentage decrease of the buildings with shear walls at corner and middle are $81.83 \%, 69.53 \%, 70 \%, 70.67 \%$, and $70.15 \%$ for rectangular, I, C, T and $\mathrm{L}$ shaped buildings respectively. Also in $\mathrm{Y}$ directions the percentage decreases are $81.83 \%$, $70.78 \%, 70.76 \%, 71.21 \%$ and $72.64 \%$.

5. Torsion in buildings during earthquake is caused due to various reasons and the most common is unsymmetrical distribution of mass and stiffness along the height of building. In some conditions such as in case of $\mathrm{C}$ shaped building along $\mathrm{Y}$ and 1 shaped buildings along $\mathrm{X}$ shows torsional irregularity greater than 1.2.

6. Buildings with shear walls in corner and middle perform well during earthquakes. Buildings with Shear wall at middle can't perform well during earthquake. But shear walls at corner and shear walls at both corner and middle are good in all conditions.

\section{REFERENCES}

[1] Darsana.P.M and Bhavya.B.S (2018) "Analysis of post-tensioned and RCC flat slabs in multi-storey framed structures by using etabs software" International Journal of Advance Engineering and Research Development - Volume 05, Issue: 04

[2] Jnanesh Reddy R K and Pradeep A R (2017) "Comparative Study of Post Tensioned and RCC Flat Slab in Multi-Storey Commercial Building" International Research Journal of Engineering and Technology - Volume: 04, Issue: 06

[3] Shriraj S. Malvade and P.J. Salunke (2017) "Analysis of PostTensioned Flat Slab by using SAFE" International Journal of Scientific Engineering and Applied Science (IJSEAS) - Volume: 03, Issue: 03

[4] Shriraj S. Malvade and P. J. Salunke (2016) "A Review on Seismic Assessment of Post-Tensioned Flat Slab" International Journal of Science Technology \& Engineering - Volume: 02, Issue: 12

[5] Pradip S. Landel, Aniket B. Raut (2015) "Seismic Behaviour of Flat Slab System" Journal of Civil Engineering and Environmental Technology - volume: 02, Issue: 10

[6] S.S. Patil, Rupali A. Sigi (2014) "Flat Slab Construction in India" International Journal of Engineering and Innovative Technology (IJEIT) ISSN: 2277-3754 ISO 9001:2008 Certified -Volume: 03, Issue: 10

[7] Boskey Bahoria, Prof.R.S.Deotale, Dr.D.K.Parbat (2010) "Comparative Design of RCC \& Post-tensioned flat slabs" Institute of Technology Nirma University, Ahmedabad - 382 481, Volume: 09, Issue: 11

[8] U. Prawatwong, C.H. Tandian and P. Warnitchai (2008) "Seismic performance of post-tensioned interior slab-column connections with and without drop panel" The 14th World Conference on Earthquake Engineering, Beijing, China - Volume: 12, Issue: 17 